\title{
EL PENSAMIENTO ALBERDIANO $Y$ LOS ENIGMAS DEL PROCESO HISTÓRICO
}

DARÍO MACOR

Texto publicado originalmente en el diario El Litoral, Santa Fe, 31 de mayo de 1994.

«Si pudiera convertir en hecho cada una de mis palabras, no escribiría una línea».

«...estoy libre del fanatismo inexperto, cuando no hipócrita, que pide libertades políticas a manos llenas para pueblos que sólo saben emplearla en crear sus tiranos. Pero deseo abundantísimas las libertades civiles o económicas, de adquirir, enajenar, trabajar...» J.B. Alberdi

Hay en Alberdi una contradicción motora que marca el derrotero de su vida política y traza el camino que será luego demasiado habitual para los intelectuales argentinos. Las dos advertencias que encabezan esta nota son oportunas en tanto traen aquí los aspectos a mi entender más duros del debate de quienes han hecho de lo público el tema central de sus reflexiones. La primera, tan breve como consistente, nos sitúa frente al intelectual tensionado entre el pensamiento y la acción, sus capacidades y limitaciones personales. La segunda, justifica una definición política destinada a imponerse y marcar su impronta en las etapas formativas del Estado y la nación argentina.

El dispositivo constitucional que Alberdi va trazando hasta en sus pliegos más suaves en los años finales del rosismo, tiene como función principal responder a lo que es vivido como una urgencia: erigir un sistema de poder alternativo que ocupe el espacio vacante que provocará la segura derrota del gobernador porteño cuyo anacronismo se ha vuelto tan evidente por sus éxitos. El mejor legado de Rosas es que "ha enseñado a los argentinos a obedecer», ha vuelto rutina la aceptación de la autoridad, ha logrado disciplinar a una sociedad tan heterogénea como dispuesta a prolongar en nombre de sus diferencias los conflictos desatados por la revolución de 1810 . 
¿Cómo mantener el duro ordenamiento que la Buenos Aires rosista ha impuesto al conjunto de las provincias argentinas sin las arbitrariedades que posibilitaron esos «logros» del jefe de la Confederación? ¿Cómo conciliar el autoritarismo que la realidad impone como necesidad, con el progresismo que se quiere tan profundo como para cambiar de raíz la sociedad, y eliminar a la vez la arbitrariedad del poder?

En los entrecruzamientos presentes en estos interrogantes, se elabora el discurso alberdiano, cuyos postulados alcanzarán una excepcional realización, tanto en la prescripción constitucional del '53 como en las fórmulas operativas que regirán los pasos de la primera república.

Y si la cuestión del orden es vivida con tal urgencia que justifica aceptar el autoritarismo como una imposición de la realidad, no lo es -como bien lo ha destacado Tulio Halperin Donghi- sólo porque los convulsionados acontecimientos sociales europeos de la década del ' 40 han vuelto mucho más cautos a los miembros de la Joven Generación, que cuando empezaron a decir su nombre en clave saintsimoniana, si no, fundamentalmente, porque ese orden encierra la clave para reservarse la capacidad de dotar de sentido a las transformaciones del desarrollo capitalista que desborda ya a los países europeos y amenaza con extender más allá de sus fronteras su fuerza homogeneizante. Para observadores tan iniciados como Alberdi, el orden se presentaba entonces como la llave que transformaba esa amenaza en oportunidad.

Este horizonte frente al problema de la autoridad seńala uno de los puntos de ruptura más significativos de esta generación con las argumentaciones con las que se había dialogado con la «cuestión estatal» en las primeras décadas posrevolucionaria. Como ha señalado oportunamente José Luis Romero «los hombres de pensamiento descubrieron la existencia de un enigma previo a todo planteo político: el enigma de la realidad social $»^{1}$. El dispositivo alberdiano debe resumir entonces su virtud en detectar y dar respuesta adecuada a ese enigma. Sólo una respuesta adecuada a la realidad social podrá alcanzar el consenso necesario para que el planteo político se realice en una matriz institucional ordenadora de la sociedad.

A diferencia de los países europeos en los que los sectores no propietarios han arribado ya al mundo de la política para quedarse; el problema fundamental de lo que todavía era Argentina sólo en el mundo de la voluntad, descansaba en las fuerzas centrífugas que desataban los conflictos internos a las elites dominantes.

\footnotetext{
${ }^{1}$ José Luis Romero, Las ideas políticas en Argentina, FCE, 1975, p. 130.
} 
Conflictos que no sólo expresaban las desinteligencias interregionales, sino también las que separaban a los sectores letrados de los dueños del poder económico.

Con el reconocimiento de un lugar privilegiado para los sectores de poder en el pacto de dominación, lo que el Alberdi de las Bases viene a decir es que su lugar, el de la elite letrada, debe tener un espacio mucho más moderado del que él mismo y sus compañeros del Salón Literario se habían asignado en los pasos iniciales. Su rol junto a Urquiza, en los diez largos años de la escisión porteña, y su desdén frente a las argumentaciones sarmientinas, confirman este renunciamiento anticipado.

Sin embargo, el reconocimiento de las situaciones provinciales y de los sectores de poder, no es suficiente para apagar una conflictividad que tiene raíces históricas y que se sostiene en la debilidad de los intereses de clase a escala nacional. Frente a este dilema la respuesta alberdiana es instrumental. El fuerte presidencialismo de su dispositivo constitucional es la herramienta más apropiada para romper una situación de empate que ha impedido una resolución hacia la unidad por el propio desarrollo de las fuerzas sociales. La organización política debe disponer entonces de toda la fuerza que está ausente en la sociedad civil.

Con la resignificación de los distintos sectores de la elite, se regula la relación entre la República de las letras y la República de la propiedad. Con el presidencialismo como instrumento central del diseño constitucional, se dota, a una instancia de origen externo a los conflictos que han caracterizado a las divisiones interregionales, de todo el poder necesario para allanar compulsivamente el camino del progreso.

Estamos ante una propuesta de desarrollo controlado del cambio social donde las exigencias de modernización económica son conciliadas con una distinción neta entre sociedad civil y sociedad política. «Una república escasamente republicana, ya que la competencia en el ámbito de la sociedad civil no debía traducirse en una mayor participación política, bloqueando entonces el pasaje del habitante, en tanto sujeto económico, al rol del ciudadano. Esta dualidad de funciones se asentaba sobre la estructura del curioso sujeto de los tiempos modernos, escindido entre un alma pública que mira al Estado y otra privada que atiende el egoísmo de su propio interés» ${ }^{2}$. En el universo de ideas alberdiano, la legitimidad de esta República sin ciudadanos descansaba en su transitoriedad y en la certidumbre de que el desarrollo libre de ese mundo del interés se conciliaría luego en una universal República de la virtud.

${ }^{2}$ Oscar Terán, «La ideología argentina en el siglo XIX», en: La Ciudad Futura, nº 1, p. 16. 
Las Constituciones, se sabe, son fruto de la voluntad política de construir un orden. Su trascendencia histórica se define por la capacidad para elaborar desde la trama institucional del texto un sistema de decisiones cuya operatividad efectiva en el tiempo depende de la aptitud para producir -en términos weberianos- una «dominación legítima». Pero es igualmente sabido que el sentido de un texto constitucional no preexiste al desarrollo del proceso político que su imposición precipita, sino que es engendrado por éste.

El resultado del entramado de ambas esferas es conocido: en 1880 un Estado nacional que gana en autonomía con respecto a la sociedad civil, es ya capaz de someter a la siempre díscola provincia de Buenos Aires y monopolizar para sí el ejercicio de la violencia legítima.

Si nos detuviéramos con mayor detalle en ese entramado entre pensamiento y proceso político, podríamos detectar las líneas de falla más significativas de las previsiones alberdianas en las que hemos puesto énfasis.

Una primera línea de falla se encuentra en esa dilemática relación entre la elite letrada y el poder económico. Dilema típico del siglo pasado que podríamos decir tiene a 1880 como punto de llegada, y que Alberdi había resuelto asignándose a sí mismo y a sus pares de la elite letrada un lugar contenido bajo el sol del poder económico. La tendencia a la diferenciación y autonomía que el Estado revela desde sus orígenes dota a los presidentes argentinos, cargados de poderes más emparentados con una monarquía que con una república, de una fuente de legitimidad predominantemente política. Con ella aquellos cuya mejor -sino única- arma política es su saber y su mayor clarividencia pueden recuperar un primer lugar en el escenario defraudando la resignación alberdiana; y ahí está Sarmiento presidente para discutirla. Este reencuentro entre saber y poder es uno de los elementos más fuertes que diferencian el caso argentino en el contexto latinoamericano en las etapas formativas del Estado y la nación.

La segunda tiene en 1880 un punto de partida que traslada hacia el futuro la confrontación de las prescripciones alberdianas con la realidad. El proceso de concentración del poder, que la misma autonomía alcanzada por el Estado facilita, termina en formas de dominación oligárquicas en las que el aparato gubernamental revela una especial aptitud para reproducirse a sí mismo. El largo reinado del orden conservador parece confirmar hasta el detalle la antigua teoría de Montesquieu: 
«Sin fuerzas sociales situadas en puntos diferentes que frenen al poder, como los accidentes geográfico detienen a los ejércitos, la separación jurídica entre legislativo, ejecutivo y judicial corre el riesgo de convertirse en una tradición inerte» ${ }^{3}$.

La importancia de esta segunda línea de falla en las prescripciones alberdianas trasciende al orden conservador en el que las formas oligárquicas de dominación alcanzaron toda su plenitud. Su diálogo con un futuro que llega hasta nuestros días se establece desde la sobrevivencia de la tendencia al hegemonismo gubernamental. La reforma política de 1912 fue el comienzo de un proceso, nada lineal por cierto, pero en el que pueden reconocerse con claridad oleadas de inclusión social que en pocas décadas terminaron por conformar un Estado mucho más universal. Sin embargo los dispositivos de reproducción del poder mantuvieron esa fuerte impronta del hegemonismo gubernamental, que como una mueca de la historia nunca nos abandona del todo, siempre sabe regresar, estar entre nosotros, obligarnos a pensar desde un no lugar: el de la negación de la tradición republicana.

${ }^{3}$ Natalio Botana, La tradición republicana, Sudamericana, 1984, p. 481. 